\title{
The importance of IT in the adaption of Activity-based costing (ABC) in Higher Education Institutions (HEI)
}

\author{
Dr. Jamalludin Helmi HASHIM. Ph.D \\ Faculty of Business Management and Accounting \\ Universiti Sultan Zainal Abidin (UniSZA), Kuala Terengganu \\ Terengganu, MALAYSIA
}

\begin{abstract}
This study intends to highlight the possible significant relationship that may exists between Information Technology (IT) in the perceived usefulness of Activity-Based Costing (ABC) information as compared to the traditional costing across three different campus clusters of higher education institutions (HEI) in Malaysia. The perceived usefulness of $A B C$ was represented by two elements, namely i) quality, and ii) functionality of costing system. The respondents were selected using disproportionate stratified random sampling method among the users of costing information in the biggest public university in Malaysia with a multi-campus university system. Among the twelve branch campuses across the country, the data was collected using structured postal questionnaires that were distributed to 96 respondents. The result indicated that there is no significant difference of perceived usefulness of information produced by $A B C$ system across all three type campus clusters under study. Furthermore, statistical analysis also shown that there is no statistically significant interaction across three types of campus clusters to affect Perception of Usefulness (POU). As the findings from this study found to be contradict from the previous studies, these might be due to the nature of a multi-campus university system which practising the centralised administration across all branch campuses. In addition to that, unlike previous studies, this study extended the applicability of IT in two dimensions of university administrations, i.e., as a support system for administration and as a management tool.
\end{abstract}

Keywords: Activity-based Costing ( $A B C)$, Survey, Information Technology (IT), Public Higher Education Institutions (PHEI), Quality and Functionality, multi-campus university system.

\section{Council for Innovative Research}

Peer Review Research Publishing System

Journal: International Journal of Management \& Information Technology

Vol. 8, No. 1

editor@cirworld.com

www.cirworld.com, member.cirworld.com 


\section{INTRODUCTION}

As proven by many researchers (for example Anderson and Young, 1999; Ray, S, 2012) that the existence of IT in ABC adoption, rejection and implementation is crucial. Particularly in the HEl environment, IT is needed to identify a significant opportunity to create competitive advantage and allow organisations to differentiate their services (Yazdani Qanbar Ali, 2012). With regard to the multi-campus university system, the higher the complexity of the cost structures, the issue whether IT is used as a support system for administration, and (ii) as a management tool, and (iii) distance learning) become more appealing.

The public universities all over the world are in a pressure to reduce operating costs (Amizawati Mohd Amir et al., 2012; Evans, 2004) as well as increase accountability (Carmo and Padovani, 2012; Mir and Rahaman, 2007). As such, these pressures will lead to the universities' administrations to have a more sophisticated costing technique to improve cost control in higher educational institutions $(\mathrm{HEI})$.

Activity-based costing ( $A B C$ ) serves to focus management attention on the cost of key activities, better understanding of what causes such costs and what changes are necessary to reduce the costs. Accordingly, ABC also provides managers with information that enables them to make decisions concerning optimal allocation of resources. Even though the $A B C$ is rapidly gaining favour in service organisations (Khrisnan, 2006; Newman, 2003; Yanpirat and Maneewan, 2012), very limited research has been done to investigate the stakeholders perception towards its usefulness prior to its implementation. The purpose of this study is to highlight the importance of IT in the ABC adaptations. As such the objectives of this study are to examine the possible significance different, i) in perceived usefulness of $A B C$ information, and ii) the different of significance of IT towards the POU across three different campus clusters of HEls.

\section{LITERATURE REVIEW}

\subsection{Activity-based costing}

ABC is a two-stage procedure used to assign overhead costs to products or services (Hilton, 2001). In the first stage, significant activities are identified, and overhead costs are assigned to activity cost pools in accordance with the way resources are consumed by the activities. In the second stage, the overhead costs are allocated from each activity cost pool to each product line in proportion to the amount of the cost driver consumed by the product line. ABC differs from traditional cost accounting, such that overhead costs are traced to products or services using cost pools and activity cost drivers rather than volume based overhead absorption rates. Basically, ABC assumes that products consume activities and activities consume overhead resources (Rajabi and Dabiri, 2012). Therefore, $A B C$ is able to measure the cost and performance of activities, resources and cost objects. $A B C$ also claimed to be able to recognise the causal relationship of cost drivers to activities (Holst and Savage, 1999) and can be viewed as "cost assignment" (refer to Figure 1: vertical axis) used for profitability analysis (Cokins, 1996). Additionally, ABC can be viewed from a process view (refer to Figure 1: horizontal axis) perspective.

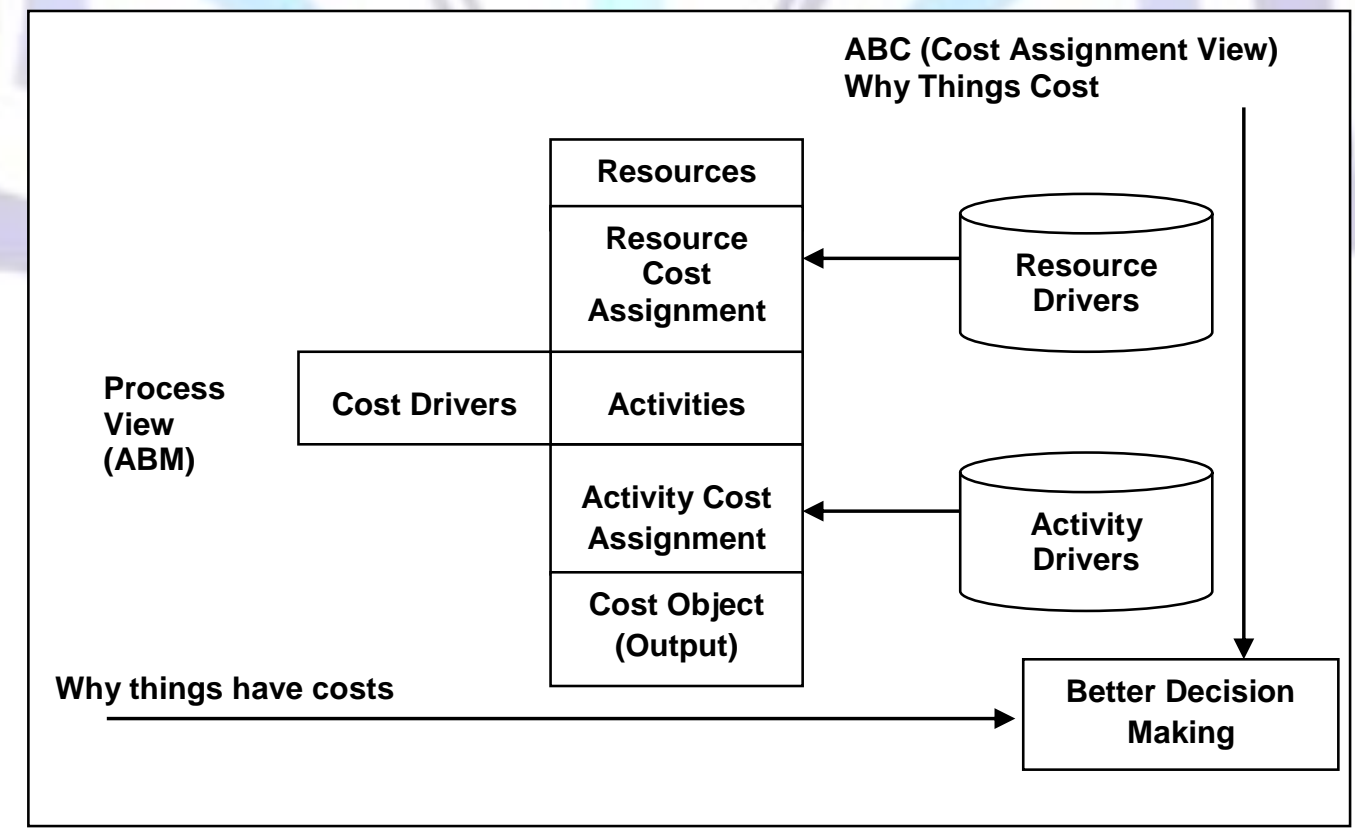

Figure 1 : Activity Based Cost Management Framework. (Source: Cokins, 1992, p.15.) 


\subsection{Benefits and reasons for adopting $A B C$}

It was established that the traditional costing system is typically associated with the unit-based system and is subject to several limitations, such as its failure to measure the resources consumed and its disability to produce accurate costing information (Aiyathurai et al., 1991; DETYA, 2000). In HEI, as can be evidently seen from the previous research findings (for example, see Zaman, 2006), ABC information is able to recognise the causal relationships between cost drivers and activities. The establishment of this relationship is useful not only in identification of unused capacity, but also important for better budget estimation and improved resource allocation as a whole.

Even though several researchers suggested that the power of $A B C$ resides in its ability to promote an enhanced understanding of the activities performed (Brimson and Antos, 1999; Turney, 1996) and to improve performance (Carmo and Padovani, 2012; Geishecker, 1996) but there are cases where, while ABC system may be favourably associated with certain job requirements on one hand, it also negatively influences others, on the other hand. A study by Hamilton and Chervany (1981), for example, concluded that while an ABC system improves decisions, it also lengthened decision time and decreased confidence. The mixed results and conflicting impact of $A B C$ implementation triggered this study to investigate the perceived usefulness of $A B C$ information prior to its implementation.

\subsection{Dimensions of information usefulness}

Literature suggested that there are two dimensions ABC information, namely (i) technical characteristics (or quality), and (ii) functionality (see Duron, 200). The term "quality" refers to five technical characteristics, namely accuracy, reliability, timeliness, accessibility and understandability. These characteristics were investigated by McGowan (1998), and suggested by the literature (for example Kaplan and Anderson, 2004) be useful only if it is of high quality while other researchers reported that "quality" of information system is negatively related to management evaluation of the overall value of the ABC (Anderson and Young, 1999).

Another dimension is called "functionality". It can be defined as the ability of a costing system to provide sufficient detail of cost information to allow costs to be analysed for different purposes (Pizzini, 2006). Pizzini (2006) claimed that a better functional cost system is a system that can provide four integrated functions: (i) greater detail, (ii) better cost classification according to behaviour, (iii) report cost information more frequently, and (iv) calculate more variances. Several studies linked the cost-system design to performance, stated in terms of a causal chain in which more functional or refined cost systems produced "better" (i.e. more relevant and useful) data (Pizzini, 2006). Studies done by several authors (for example, Johnson, 1992; Troutt et al., 2003) noted that this linkage enhances the managerial decision making and leads to improve economic performance.

While more detailed and frequent cost data is proven to be useful in a single setting (Feltham, 1977; Hilton, 1979), an adverse result is shown in multi-firm settings (Banker and Johnston, 1993; Banker and Potter, 1993; Callahan and Gabriel, 1999). There is evidence to show that strategic behaviour can bring about conditions in which less informative product-cost data are optimal (Banker and Johnston, 1993; Callahan and Gabriel, 1999).

This study will not only combine both dimensions of information characteristics of costing information, i.e., quality and functionality (which have previously been investigated separately) but will also use the multi setting of university's management. This is expected to provide valuable insights by providing comprehensive meaning of perception and lead to better and more convincing conclusion.

\subsection{University of Excellence (UoE)}

University of Excellent (UoE) is the biggest multi-campus university in the Malaysia, with twelve branch campuses throughout the country. It receives the biggest allocation of Malaysia's annual budget for higher education and also the biggest university in the country in terms of number of programmes offered (almost 300 programmes) and student intake (almost 20000 student per session). The programmes are divided into three clusters: (i) Science and Technology (ST), (ii) Social Sciences and Humanities (SSH) and (iii) Business and Management (BM). The complexities in term of number of student, number of programmes offered as well of a multi-campus structure of its administration, provide a better population to investigate its stakeholders' perception towards any management accounting innovations. Table 1 shows the UoE academic structure.

Table 1 : Academic Administration in UoE

\begin{tabular}{|c|c|c|}
\hline Clusters & Stream & Faculties \\
\hline $\begin{array}{l}\text { Science and } \\
\text { Technology }\end{array}$ & Science & $\begin{array}{l}\text { Faculty of Applied Sciences } \\
\text { Faculty of Information Technology and Quantitative } \\
\text { Sciences } \\
\text { Faculty of Architecture, Planning and Surveying }\end{array}$ \\
\hline
\end{tabular}




\begin{tabular}{||l|l|l||}
\hline & & Faculty of Sports Science and Recreation \\
\hline & Medical Science & $\begin{array}{l}\text { Faculty of Medicine } \\
\text { Faculty of Health Sciences } \\
\text { Faculty of Pharmacy } \\
\text { Faculty of Dentistry }\end{array}$ \\
\hline & Engineering & $\begin{array}{l}\text { Faculty of Chemical Engineering } \\
\text { Faculty of Civil Engineering } \\
\text { Faculty of Electrical Engineering } \\
\text { Faculty of Mechanical Engineering }\end{array}$ \\
\hline $\begin{array}{l}\text { Social Sciences } \\
\text { and Humanities }\end{array}$ & Social Sciences & $\begin{array}{l}\text { Faculty of Law } \\
\text { Faculty of Administrative Science \& Policy Studies } \\
\text { Faculty of Communication and Media Studies }\end{array}$ \\
\hline & Humanities & $\begin{array}{l}\text { Faculty of Music } \\
\text { Faculty of Art and Design } \\
\text { Faculty of Education } \\
\text { Faculty of Artistic \& Creative Technology }\end{array}$ \\
\hline $\begin{array}{l}\text { Business and } \\
\text { Management }\end{array}$ & $\begin{array}{l}\text { Business and } \\
\text { Management }\end{array}$ & $\begin{array}{l}\text { Faculty of Accountancy } \\
\text { Faculty of Business Management } \\
\text { Faculty of Hotel and Tourism Management } \\
\text { Faculty of Information Management } \\
\text { Faculty of Office Management \& Technology }\end{array}$ \\
\hline
\end{tabular}

\subsection{Different cluster and different type of cost information}

As literature provided evidences that (see Lin, 2000) due to greater diversity of instructional delivery methodology, instructional resources, enrolments across majors, and indirect costs, the ABC system seems to be more suited for public HEls. Wilkinson and Yussof (2005) reported that the cost per student across clusters was significantly different. For example, the costs for Art and Social Sciences programme is RM2,781.85; Economics and Business Studies, RM2,219.35; and Engineering and Technology, RM4,443.28. The reason for this was due to the teaching facility and equipment in the S\&T cluster being more expensive than for the SSH cluster (Wilkinson and Yussof, 2005). A similar pattern can be observed in another study done by Atarek Kamil Ibrahim and Co (2005), which revealed substantial disparities in the cost per student across universities and programmes or courses. For example, the highest cost per student was recorded in UNIMAS amounting to RM15,291 and RM26,977 for the courses in the Faculty of Accountancy and Business Management and the Faculty of Engineering respectively. Universiti Putra Malaysia (UPM) which recorded the lowest costs, also reported disparities between these two programmes, (RM5,487 for Faculty of Accountancy and Business Management as compared to RM11,713 for the Faculty of Engineering). Due to the different cost levels and different cost structures, it is to be expected that $A B C$ information may be useful for different campus clusters. In the case of UoE, it classifies its campus into three clusters, namely (i) Science and Technology (S\&T), (ii) Social Sciences and Humanities (SSH) and (iii) Business Management (BM). Based on the above discussion, it is expected that the S\&T campuses - which utilise different tools for teaching and learning (T\&L) as compared to SSH campus - will perform different activities and therefore, appear to have different cost structure. As a result, it is expected that the different campus types perceive the usefulness of $A B C$ information differently.

\subsection{Application of IT in HEI}

The existence of IT in adoption, rejection and implementation of $A B C$ is crucial (Anderson and Young, 1999; Krumwiede, 1998). Particularly in the HEI environment, IT is also needed to identify a significant opportunity to create competitive advantage and allow organisations to differentiate their services (Lin, 2000). The application of IT in a multi-campus university system will change the complexity of the cost structures, whether IT is used for, i) administration purposes, ii) as a management tools, or iii) as a mode of teaching delivery. Previous studies however (see Duron, 2000; Richardson, 2001), focused only on the application of IT as a mode of teaching delivery. The application of IT in distance education will also lead to the difficulty of measuring the costs associated with the individual course and programme (Burton, 1998; Duron, 2001; Poley, 1998; Richardson et al., 2001). This study will extend the applicability of IT in two dimensions of university administrations, i.e., as a support system for administration and as a management tool. Particularly in Malaysian HEls landscape, several transformations can be seen, such as the increased number and "type or form" of HEls including managing foreign branch campuses, 
administrating life-long learning and multi-disciplinary programmes. These transformations will lead to the commitment towards IT is expected to have a significant relationship with the perceived usefulness of $A B C$ information, particularly in a multi-campus public university system.

\section{THEORETICAL FRAMEWORK AND HYPOTHESES DEVELOPMENT}

Due to the fact that $A B C$ is not yet implemented in Malaysian higher education environment, the understanding of the perceived usefulness of $A B C$ information in comparison with information produced by traditional costing system is crucial to guarantee the successful implementation of the ABC system.

\subsection{Different perceptions of among campus cluster}

It has been suggested that particular stakeholders perceived the usefulness of $A B C$ information differently (Jarrar et al., 2007; McGowan, 1998). McGowan (1998), for example, reported that preparers perceived ABC more favourably than do the users, particularly with respect to the quality of their work and their effectiveness on the job.

As such, several authors (as cited above) indirectly agreed on the benefits of ABC were not equally acknowledged by stakeholders, the investigation on the "end user" perception (i.e., users) need to be clearly understood. A finding reported by several authors (for example, Pizzini, 2006) noted that the implementation of cost management systems must consider the heterogeneity of needs and potential reactions of the individual within site, and the reactions can only be indicated through their perceived usefulness of $A B C$ information. Other than that, as the end user of the information particularly in public sector, the positive perception from them (users) is crucial to maximise the benefit of information produced by ABC system. These beliefs developed the following hypotheses to be tested, followed by the research framework of hypothesis 1 in the Figure 2.

H1: There is a significant difference perception of the usefulness of costing information produced by an ABC system across campus clusters of $\mathrm{UoE}$

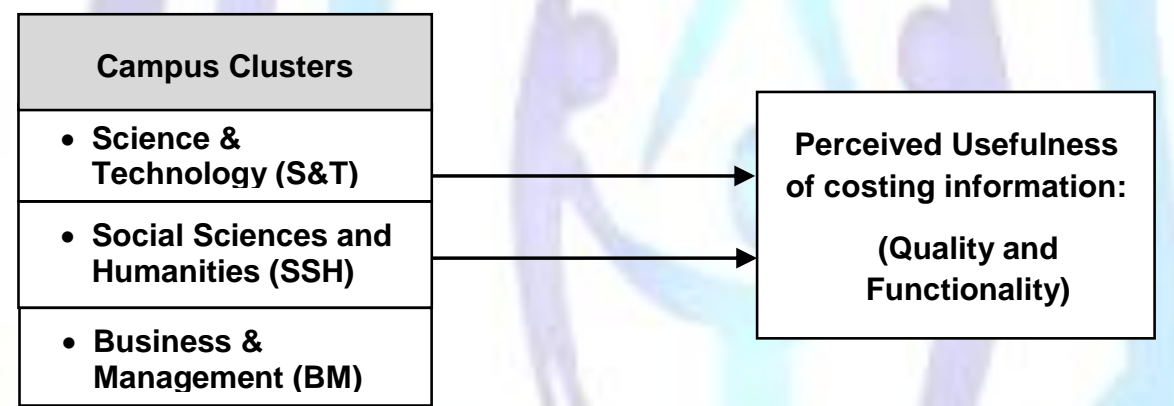

Figure 2 : Perceived Usefulness of Costing Information:

Respondents perception towards ABC System

\subsection{IT and ABC adaption across campus clusters}

As noted earlier, the application of IT in a HEI only focused on the application of IT as a mode of teaching delivery. Particularly in Malaysian HEls landscape, several transformations can be seen, such as the increased number and "type or form" of HEls including managing foreign branch campuses, administrating life-long learning and multidisciplinary programmes. These transformations will lead to the commitment to IT is expected to have a significant relationship with the perceived usefulness of $A B C$ information, particularly in a multi-campus public university system. As such, will extend the applicability of IT in two dimensions of university administrations, i.e., as a support system for administration and as a management tool as noted by the following hypotheses statement.

H2: $\quad$ There is no significant different between the Financial commitment to IT (for the administrations) and the perceived usefulness of $A B C$ information across campus clusters.

H3: There is no significant different between the financial commitment to IT (Management tools) and the perceived usefulness of $A B C$ information across campus clusters.

H4: There is no significant different between the financial commitment to IT (distance learning) and the perceived usefulness of $A B C$ information across campus clusters.

\section{RESEARCH METHODOLOGY}

This study utilised the survey approach using postal questionnaire based on the perceptions of respondents towards the usefulness of costing information produced by $A B C$ system. Using the disproportionate stratified random sampling, a total of 181 questionnaires was posted to respondents in thirteen campuses of UoE including its main 
campus. The population of this study comprised of three hundreds and ninety nine (399). Table 2 listed in full the respondent and sample of this study.

Table 2 : Population and Sample Size:

Disproportionate Stratified Random Sampling

\begin{tabular}{||l|l|c|c|c||}
\hline \multirow{2}{*}{ No. } & \multicolumn{1}{|c|}{ Campus Campuses } & \multicolumn{3}{||}{ Respondents } \\
\cline { 3 - 5 } & & $\begin{array}{c}\text { Population } \\
(N)\end{array}$ & $\%$ & Sample (S) \\
\hline \hline 1 & Business and Management (BM) & 362 & 90.21 & 129 \\
\hline 2 & Science Social and Humanities (SSH) & 10 & 2.8 & 4 \\
\hline 3 & Science and Technology (S\&T) & 27 & 6.99 & 10 \\
\hline & & 399 & & 143 \\
\hline
\end{tabular}

The survey questions were in the form of closed-ended questions (except one question) based on a five-point Likert scale. The questionnaire consists of 17 questions which are divided into two main parts. Part One initiates enquiries regarding some general information (five questions), followed by Part Two regarding the perceived usefulness of $A B C$ information, five questions for quality, four questions for functionality and three questions for overall usefulness.

The questionnaire was pilot tested on the sample of 20 individuals to get some respond on the consistency and reliability of words, sentences etc. There were several modifications made including questionnaire format, the consistent use and grouping of the Likert-scale questions within a single section. A number of questions were reworded to enable more precise interpretation, specifically for the potential of cost distortion, decision usefulness and financial commitment to technology and the perception of $A B C$ information. Instructions to the respondents emphasised the need to answer the survey questions from the perspective of their respective function and role in organisation.

\section{RESULTS AND DISCUSSIONS}

\subsection{Descriptive analysis}

The response rate of approximately 67.13 percent (96 of 143 respondents) was obtained from the sample of thirteen campuses which consisted of three types of campus cluster. Chart 1 showed the statistic of completed questionnaire returned.

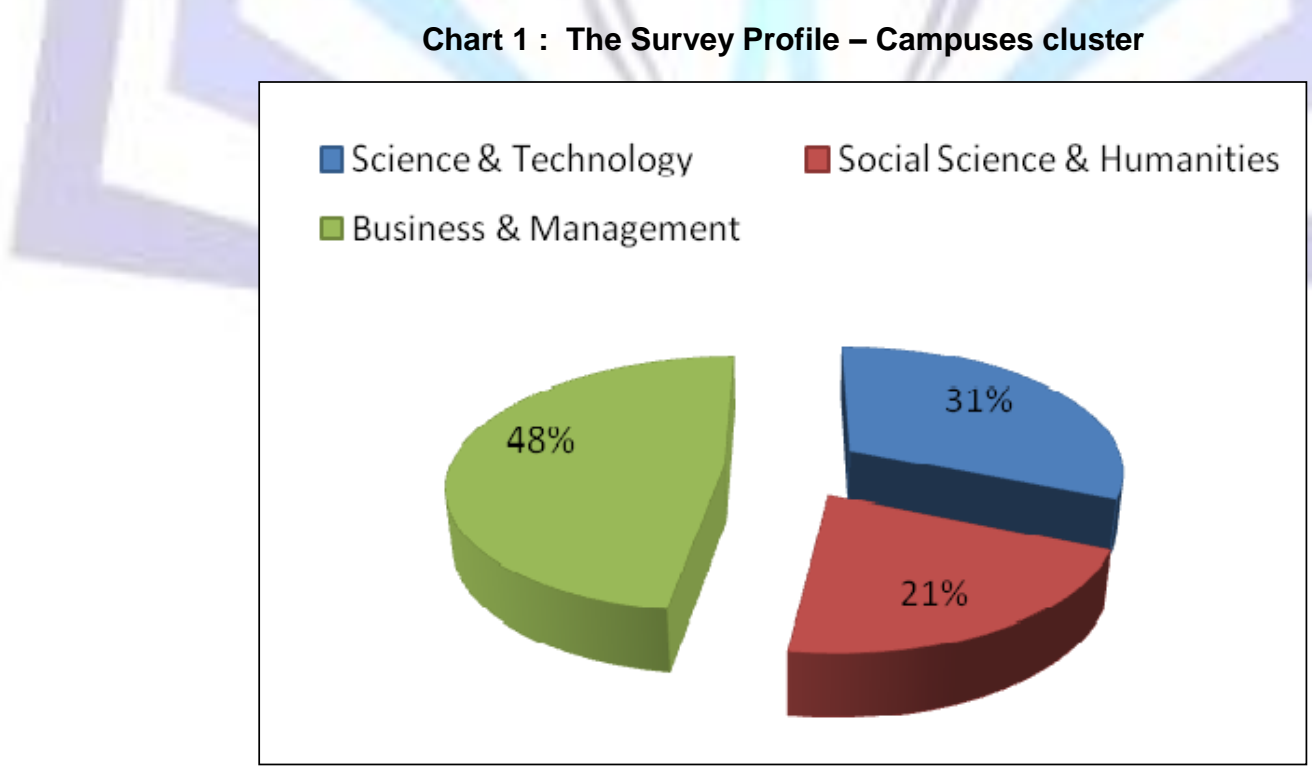

Table 3 displays the information on the respondents' based on campus clusters. As can be seen, the biggest representatives come from the BM's campus clusters (48\%), followed by S\&T (31\%) and the least is Social Science \& Humanities (21\%) 
Table 3 : Respondents

\begin{tabular}{||l|r|r|r|r||}
\hline \multicolumn{1}{|c|}{ Campus Clusters } & Frequency & Percent & \multicolumn{1}{|c|}{$\begin{array}{c}\text { Valid } \\
\text { Percent }\end{array}$} & $\begin{array}{c}\text { Cumulative } \\
\text { Percent }\end{array}$ \\
\hline \hline Science \& Technology & 42 & 31.3 & 31.3 & 31.3 \\
\hline Social Science \& Humanities & 28 & 20.9 & 20.9 & 52.2 \\
\hline Business \& Management & 64 & 47.8 & 47.8 & 100.0 \\
\hline Total & 134 & 100.0 & 100.0 & \\
\hline
\end{tabular}

There were three preliminary tests, namely (i) Normality test, ii) t-test for non-response bias, and (iii) measures of central tendency. The data fulfilled the normality assumption using skewness method which indicates that for all of the variables belong within the \pm 2.0 range. For the non-response bias, the result for t-test showed that only three items (out of 17) were found to have a significant difference between batches. Therefore, it could be concluded that there was no material non-response bias for the items listed in the questionnaire. Measures of the central tendency and dispersion for the dependent and independent variables were obtained. All variable measurements were obtained on a five point Likert-scale from $1=$ strongly disagree to $5=$ strongly agree.

Table 4 : The campus cluster and Financial Commitment towards IT

\begin{tabular}{|c|c|c|c|c|c|}
\hline Panels & Dependent Variable & Mean & Std Devn & Minimum & Maximum \\
\hline 1 & Perceived Usefulness (POU) & 3.729 & 0.83 & 1.00 & 5.00 \\
\hline \multirow{4}{*}{2} & FCITa & 3.7813 & .63583 & 3.00 & 5.00 \\
\hline & FCITb & 3.9167 & .64346 & 3.00 & 5.00 \\
\hline & FCITC & 3.5000 & .66491 & 2.00 & 5.00 \\
\hline & Campus Type & 2.2708 & .83954 & 1.00 & 3.00 \\
\hline
\end{tabular}

Table 4 show the mean scores (MS) and standard deviation (SD) of perceived usefulness of ABC information, noted by 3.73 and 0.83 , respectively. The highest mean score was noted by FCITb, followed by FCITa and POU. The highest standard deviation was scored by the Campus types $(0.84)$, followed by POU $(0.83)$ and FCITc $(0.665)$.

\subsection{Perception of Usefulness (POU) of ABC system across campus cluster.}

Hypothesis one was developed to investigate if there is any significant difference in perception about the usefulness of $A B C$ information among the campus cluster.

Table 5 : Perception of Usefulness (POU) of ABC system across campus cluster

\begin{tabular}{|l|r|}
\hline & \multicolumn{1}{|c|}{ POU } \\
\hline \hline Chi-Square & 2.454 \\
Df & 2 \\
Asymp. Sig. & .293 \\
\hline
\end{tabular}

a. Kruskal Wallis Test

b. Grouping Variable: Cluster

Table 5 shows the result of the Kuskal Wallis test statistical which evidently indicates that the null hypothesis cannot be rejected ( $p>0.05 ; p=0.293$ ). As such there is to conclude that there is no significance different of POU across three campus cluster under study.

\subsection{IT and the Usefulness of ABC system across campus cluster.}


Hypotheses two, three and four noted that there is no significant different between the financial commitment to IT to the administrations $(\mathrm{H} 2)$, management tools $(\mathrm{H} 3)$ and distance learning $(\mathrm{H} 4)$ and the perceived usefulness of $A B C$ information across campus clusters.

The result of the two-way ANOVA was run to indicate whether the two independent variables or their interaction are statistically significant is shown in the Table 6 Tests of Between-Subjects Effects, below:

Table 6 : Tests of Between-Subjects Effects: POU

\begin{tabular}{||l|r|r|r|r|r||}
\hline Source & \multicolumn{1}{|c|}{$\begin{array}{c}\text { Type III } \\
\text { Sum of } \\
\text { Squares }\end{array}$} & \multicolumn{1}{c|}{ Df } & \multicolumn{1}{c|}{$\begin{array}{c}\text { Mean } \\
\text { Square }\end{array}$} & F & Sig. \\
\hline \hline Corrected Model & $29.985^{\mathrm{a}}$ & 32 & .937 & 1.688 & .038 \\
\hline Intercept & 377.019 & 1 & 377.019 & 679.143 & .000 \\
\hline Cluster * FCITa & 0.655 & 2 & .328 & .590 & .557 \\
\hline Cluster * FCITb & 2.953 & 3 & .984 & 1.773 & .161 \\
\hline Cluster * FCITc & 1.902 & 2 & .951 & 1.713 & .189 \\
\hline
\end{tabular}

a. $\mathrm{R}$ Squared $=.462$ (Adjusted R Squared $=.188$ )

As the results indicated that there are no statistically significant interaction across three types of campus clusters (FCITa, $p=.557$; FCITb, $p=0.161$; FCITc, $p=0.189$ ). For further confirmation, the result from Tukey HSD test showed in Table 7 below indicated the result of a Multiple Comparisons which confirmed the no statistically significant difference towards the IT and POU among all three different campus clusters $(p>.005)$.

Table 7 : Multiple Comparisons (Tukey HSD)

\begin{tabular}{|c|c|c|c|c|c|c|}
\hline \multirow[t]{2}{*}{ (I) Cluster } & \multirow[t]{2}{*}{ (J) Cluster } & \multirow{2}{*}{$\begin{array}{l}\text { Mean } \\
\text { Differen } \\
\text { ce }(I-J)\end{array}$} & \multirow[t]{2}{*}{$\begin{array}{l}\text { Std. } \\
\text { Error }\end{array}$} & \multirow[t]{2}{*}{ Sig. } & \multicolumn{2}{|c|}{$\begin{array}{l}\text { 95\% Confidence } \\
\text { Interval }\end{array}$} \\
\hline & & & & & $\begin{array}{l}\text { Lower } \\
\text { Bound }\end{array}$ & $\begin{array}{l}\text { Upper } \\
\text { Bound }\end{array}$ \\
\hline $\begin{array}{l}\text { Science \& } \\
\text { Technology }\end{array}$ & $\begin{array}{l}\text { Social Science \& } \\
\text { Humanities } \\
\text { Business \& } \\
\text { Management }\end{array}$ & $\begin{array}{l}.0568 \\
.2550\end{array}$ & $\begin{array}{l}.21992 \\
.18502\end{array}$ & .358 & $\begin{array}{l}-.4711 \\
-.1891\end{array}$ & $\begin{array}{l}.5847 \\
.6991\end{array}$ \\
\hline $\begin{array}{l}\text { Social Science \& } \\
\text { Humanities }\end{array}$ & $\begin{array}{l}\text { Science \& Technology } \\
\text { Business \& } \\
\text { Management }\end{array}$ & $\begin{array}{r}-.0568 \\
.1982\end{array}$ & $\begin{array}{l}.21992 \\
.19062\end{array}$ & $\begin{array}{l}.964 \\
.555\end{array}$ & $\begin{array}{l}-.5847 \\
-.2594\end{array}$ & $\begin{array}{l}.4711 \\
.6557\end{array}$ \\
\hline $\begin{array}{l}\text { Business \& } \\
\text { Management }\end{array}$ & $\begin{array}{l}\text { Science \& Technology } \\
\text { Social Science \& } \\
\text { Humanities }\end{array}$ & $\begin{array}{l}-.2550 \\
-.1982\end{array}$ & $\begin{array}{l}.18502 \\
.19062\end{array}$ & $\begin{array}{l}.358 \\
.555\end{array}$ & $\begin{array}{l}-.6991 \\
-.6557\end{array}$ & $\begin{array}{l}.1891 \\
.2594\end{array}$ \\
\hline
\end{tabular}

Based on observed means. The error term is Mean Square(Error) $=.555$.

\section{CONCLUSION, LIMITATIONS AND DIRECTION FOR FUTURE STUDIES}

\subsection{Conclusions}

Table 5 displays the result of the Kuskal Wallis test for the perceived usefulness of ABC system across the campus cluster. As indicated, there is no significant difference of perceived usefulness of information produced by $A B C$ system ( $p>0.05: p=0.29$ ) across all three types campus clusters under study. This result indicated an inconsistency with the earlier claim that the different cost information was needed for different campus cluster (Abusalama, 2008; Reid and Smith, 2000). 
Furthermore, statistical analysis also shown that there is no statistically significant interaction across three types of campus clusters. These are also confirmed by the Tukey post hoc test results. As such, even though literature noted that there were significant functions of IT for different types of campus clusters (see Lin, 2000), but the findings from this study showed otherwise. This might be due to the nature of a multi-campus university system which practising the centralised administration across all branch campuses, regardless of the types of campus cluster (either BM, S\&T or SSH). Furthermore, previous studies (see Duron, 2001; Richardson, 2001) only focused on the application of IT as a mode of teaching delivery but this study extended the applicability of IT in two dimensions of university administrations, i.e., as a support system for administration and as a management tool. The findings also confirmed that particularly in Malaysian HEls landscape, the importance of IT has remained crucial in the adaptation of ABC across all three types of campus cluster under study.

\subsection{Limitations}

The present study is subjected to several limitations. First, although tests were performed to address the issue of non-response bias, there was no way to ascertain whether the non-respondents were systematically different from the respondents. Thus, the perceived usefulness found towards the usefulness of $A B C$ across campus cluster cannot be assured without any doubt and can only be valid within a specific context. Second, the present study is limited to a single university with several branch campuses throughout Malaysia. As such, generalising the results of the study in this population should be done with extreme caution. This is due to the nature of a multi-campus public university system which might be different from a single campus public university system or even the private university system (either a single campus or multi-campus). Therefore, future studies concerning the stakeholders need to be undertaken with extreme caution to ensure the findings can represent the actual perception of users and preparers.

In addition to the methodological limitations noted above, there were few limitations found from a technical perspective. For example, more specific instructions in the cover letter(s) and / or survey instrument might have included an advise to the recipient (i.e., in cases where he / she was not the addressee) to forward the instrument to the appropriate person in the organisation (i.e., campus director). Inclusion of this wording is expected to prevent the return of a number of incomplete instruments which may contribute to the increase in the survey response rate. While it is possible (particularly in this setting of public multi-campus university), the differences in cost management practices and/or environmental factors may be influenced by funding policies and other factors that are similar in nature. Replication of the entire study would be necessary to investigate and confirm the validity of these contextual factors in different settings of the multi-campus university environment.

\subsection{Directions for Future Research}

The present study was focused to examine the differences perceptions among three types of campus clusters with regard to their usefulness. Furthermore, the study also investigated the possible differences functions of IT in the ABC adaptation.

Further study need to be done to further explain the function of IT across all types of HEI (private and public). Besides, the insight and detailed specification of variables is crucial to provide the respondents with the element of significance of those variables towards the perceived usefulness of $A B C$ information. Better measures and more specification of key variables could also enhance the findings of future studies.

\section{REFERENCES}

[1] Abusalama, F. A. (2008). Barriers to Adopting Activity-Based Costing Systems (ABC) : An Empirical Investigation using Cluster Analysis. Unpublished PhD thesis, Dublin Institute of Technology.

[2] Aiyathurai, G., Cooper, W. W., and Sinha, K. K. (1991). Note On Activity Accounting Accounting Horizons, 5(4), 60 - 68.

[3] Amizawati Mohd Amir, Sofiah Md. Auzair, Ruhanita Maelah, and Azlina Ahmad. (2012). Determination of Educational Cost in Public University - A Modified Activity Based Approach. World Journal of Social Sciences, 2(2), 34 - 48.

[4] Anderson, S. W., and Young, S. M. Y. (1999). The impact of contextual and process factors on the evaluation of activity-based costing systems. Accounting, Organizations and Society, 24, 525 - 559.

[5] Banker, R. D., and Johnston, H. H. (1993). An Empirical Study of Cost Drivers in the U.S. Airline industry. The Accounting Review, 68(3), 576 - 601.

[6] Banker, R. D., and Potter, G. (1993). Economic implications of single cost driver systems. Journal of Management Accounting Research, 5, 15 - 31. 
[7] Brimson, J. A., and Antos, J. (1999). Driving Value Using Activity-Based Budgeting. New York: John Wiley \& Sons, Inc.

[8] Burton, N. (1998). Calculating the cost of an undergraduate Initial Teacher Education (ITE) course. International Journal of Educational Management, 12(6), 260 - 269.

[9] Callahan, C. M., and Gabriel, E. A. (1999). The differential impact of accurate product cost information in imperfectly competitive markets: A theoretical and empirical investigation. Contemporary Accounting Research, 15, 419 - 455.

[10] Carmo, L. P. F., and Padovani, F. (2012). Advances and Challenges for Adoption of Activity Based Costing (ABC) by Public Sector: A Comparative Study of Brazil, Colombia, Uruguay and United States. International Business Research 5(2), 150 - 158.

[11] Cokins, G. (1996). Activity-Based Cost Management: Making it Work. New York McGraw Hill.

[12] DETYA. (2000). A Study to Develop a Costing Methodology for the Australian Higher Education Sector: Department of Education, Training and Youth Affairs, University of Newcastle. Australia.

[13] Duron, R. W. (2001). Factors Associated with the perceived benefits of Activity-Based Costing in nonprofit institutions of higher learning. Unpublished (PhD Thesis, Capella University), Capella.

[14] Evans, T. M. (2004). Activity-Based Costing at Colleges and Universities: Understanding, Communicating and Controlling Costs Associated with Educating Different Student Groups. Unpublished PhD Thesis, The University of Texas at Austin, Texas.

[15] Feltham, G. A. (1977). Cost aggregation: An information economic analysis. Journal of Accounting Research, 15, 42 - 70.

[16] Geishecker, M. L. (1996). New technologies support ABC. Management Accounting (March), 42 - 48.

[17] Hilton, R. (1979). The determinants of cost information value: An illustrative analysis. Journal of Accounting Research, 17(2), 411 - 435.

[18] Hilton, R. W. (2001). Managerial Accounting : Creating Value in a Dynamic Business Environment (5th ed.). New York: McGraw Hill, Irwin.

[19] Holst, R., and Savage, R. J. (1999). Tools and Implementing Activity-Based Management. In S. Player \& R. Lacerda (Eds.), Arthur Andersen's Global Lessons in Activity-Based Management (pp. 268). New York: John Wiley \& Sons, Inc.

[20] Jarrar, N. S. b., Smith, M., and Dolley, C. (2007). Perceptions of preparers and users of accounting change : a case study in an Australian university. Managerial Auditing Journal, 22(1), 80 - 94.

[21] Khrisnan, A. (2006). An application of Activity Based Costing in higher learning institution : A local case study. Comtemporary Management Research, 2(2), 75 - 90.

[22] Krumwiede, K. R. (1998). The implementation stages of activity-based costing and the impact of contextual and organisational factors. Journal of Management Accounting Research, 10, 239 - 275.

[23] Lin, B.-R. (2000). Institutional characteristics that support activity based costing and business officers' perception regarding cost management. Unpublished PhD Thesis, University of South Dakota, Dakota.

[24] McGowan, A. (1998). Perceived Benefits of ABCM Implementation. Accounting Horizons, 12(1), 31 - 50.

[25] Mir, M. Z., and Rahaman, A. S. (2007). Accounting and public sector reforms: A study of a continuously evolving governmental agency in Australia. Accounting Auditing \& Accountability Journal, 20(2), 237 - 267.

[26] Newman, J. E. (2003). Activity-Based Costing in User Services of an Academic Library. Library Trends, $51(3), 333-348$.

[27] Pizzini, M. J. (2006). The relation between cost-system design, managers' evaluations of the relevance and usefulness of cost data, and financial performance: an empirical study of US hospitals. Accounting, Organizations and Society, 31, 179 - 210.

[28] Poley, J. K. (1998). Distance education for American universities and the world. American Journal of Agricultural Economics, 80(5), 973 - 979.

[29] Rajabi, A., and Dabiri, A. (2012). Applying Activity Based Costing (ABC) Method to Calculate Cost Price in Hospital and Remedy Services. Iranian Journal of Public Health, 41(4), 100 - 107. 
[30] Reid, G. C., and Smith, J. A. (2000). The impact of contingencies on management accounting system development. Management Accounting Research, 11, 427 - 450.

[31] Richardson, W. D., Ford, E. W., Slovensky, D. J., and Menachemi, N. (2001). The information superhighway - are management faculty still parked in the driveway. Journal of Education for Business, 77(1), 57 - 61.

[32] Turney, P. B. B. (1996). Activity Based Costing The Performance Breakthrough. Portland, Oregon: Kogan Page.

[33] Wilkinson, R., and Yussof, I. (2005). Public and private provision of higher education in Malaysia: A comparative analysis. Higher Education, 50, 361 - 386.

[34] Yanpirat, P., and Maneewan, J. (2012). Employing Fuzzy-Based CVP Analysis for Activity-Based Costing for Maintenance Service Providers. Paper presented at the International Multiconference of Engineering and Computer Scientists (IMECS), Hong Kong.

[35] Yazdani Qanbar Ali. (2012). Investigating the Cost of Educating Per-Student using Activity Based Costing (ABC) System in Islamic Azad University Qaemshahr Branch. American Journal of Scientific Research(62), $94-100$.

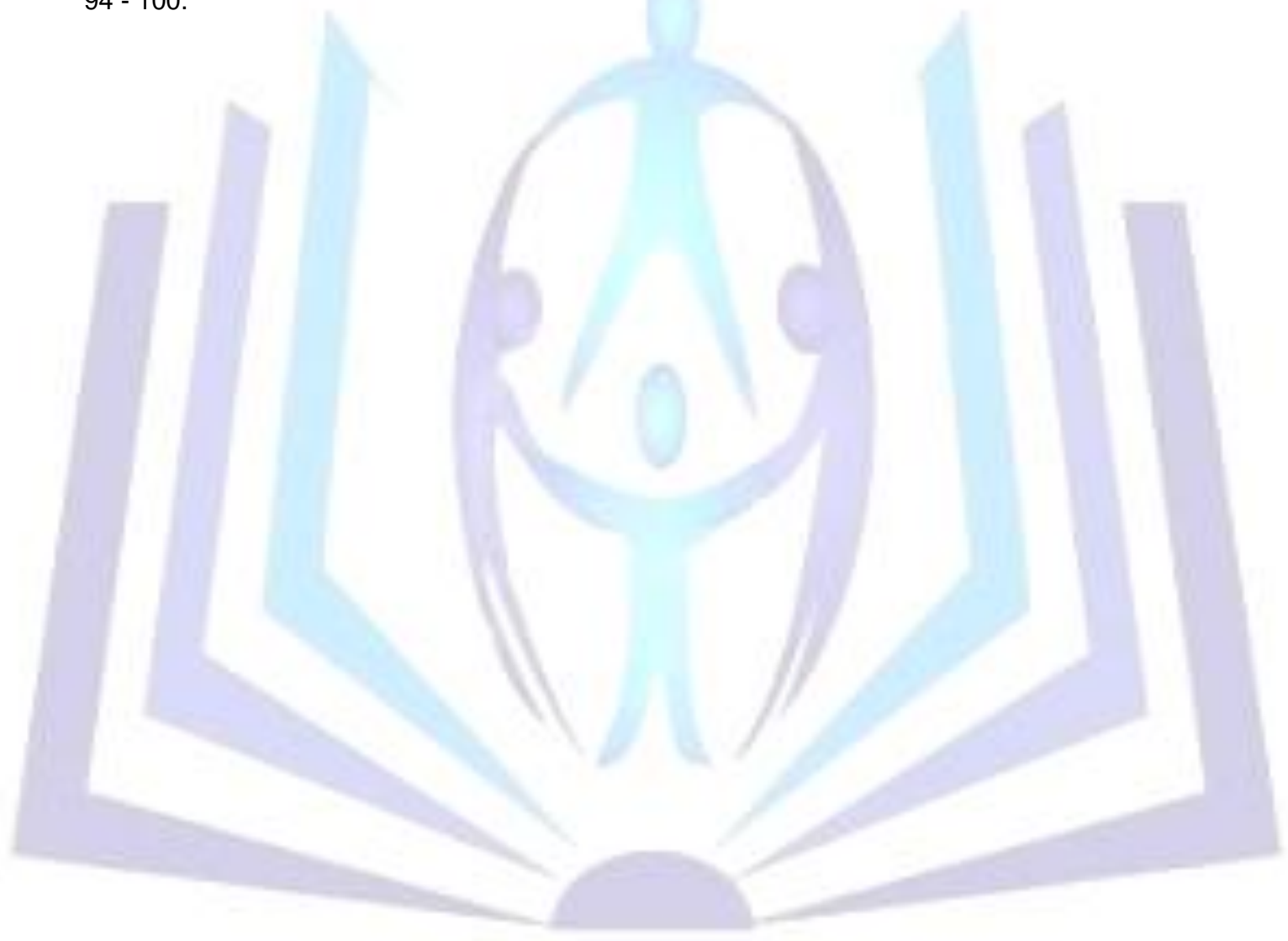

